\title{
Phenolic Acids Content and Nutritional Quality of Conventional, Organic and Biodynamic Cultivations of the Tomato CXD271BIO Breeding Line (Solanum lycopersicum L.)
}

\author{
Laura D’Evoli, Massimo Lucarini, Josè Sánchez del Pulgar, Altero Aguzzi, Paolo Gabrielli, \\ Loretta Gambelli, Ginevra Lombardi-Boccia*
}

CREA - Food and Nutrition, Rome, Italy

Email: *g.lombardiboccia@crea.gov.it

How to cite this paper: D'Evoli, L., Lucarini, M., del Pulgar, J.S., Aguzzi, A., Gabrielli, P., Gambelli, L., Lombardi-Boccia, G. (2016) Phenolic Acids Content and Nutritional Quality of Conventional, Organic and Biodynamic Cultivations of the Tomato CXD271BIO Breeding Line (Solanum lycopersicum L.). Food and Nutrition Sciences, 7, 1112-1121.

http://dx.doi.org/10.4236/fns.2016.712106

Received: July 7, 2016

Accepted: October 16, 2016

Published: October 20, 2016

Copyright $\odot 2016$ by authors and Scientific Research Publishing Inc. This work is licensed under the Creative Commons Attribution International License (CC BY 4.0).

http://creativecommons.org/licenses/by/4.0/

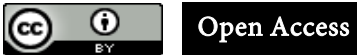

\section{Abstract}

This study was undertaken to evaluate the influence of growing systems (conventional, organic and biodynamic performed with two types of manuring) on some nutritional traits of the tomato breeding line CXD271BIO (Solanum lycopersicum L.). Experimental fields were in the same geographical area and the cultivations were performed over five years. The content of macronutrients, minerals $(\mathrm{Ca}, \mathrm{K}, \mathrm{Mg}, \mathrm{P}$, $\mathrm{Na}$ ), trace elements ( $\mathrm{Fe}, \mathrm{Zn}, \mathrm{Cu}, \mathrm{Mn}$ ) and phenolic acids (chlorogenic, caffeic, $p$-coumaric and ferulic acids) was determined. The biodynamic A growing system showed the highest protein and carbohydrates content compared to the other growing systems. Data on minerals and trace elements content showed significant differences (mainly in $\mathrm{Ca}, \mathrm{Na}, \mathrm{Fe}$ and $\mathrm{Zn}$ content) between conventional and biodynamic tomatoes, whereas no major impact of the fertilization among organic and the two biodynamic growing systems was observed. Appreciable differences in phenolic acids biosynthesis were observed, with the year of harvest showing a marked effect especially on chlorogenic, $p$-cumaric and ferulic acids content. Conversely, the cultivation system did not show major influence. Principal Components Analysis (PCA), performed on mineral and phenolic acids content, substantiated the large effect of the year of harvest, also suggesting an effect of the conventional cultivation system.

\section{Keywords}

Tomato, Conventional, Organic, Biodynamic, Phenolic Acids, Minerals, Trace Elements 


\section{Introduction}

Tomato is one of the most consumed crops in Italy. The last national food consumption survey highlighted daily tomato consumption in Italy of $75 \mathrm{~g}(41.9 \mathrm{~g} /$ day raw and 34.1 $\mathrm{g} /$ day tomato-based products) [1]. This high tomato daily consumption contributes to the intake of a number of secondary metabolites considered beneficial for human health. Among these, phenolic compounds have long been recognized for their potentially protective effect on human health exerted through several complementary pathways (antioxidant, anti-inflammatory, anti-proliferative and cell-signaling properties) [2]-[4]. Phenolic acids in plants are mainly involved in the tissue defense against infection by pathogen or damage by ultraviolet radiation. Multiple stressing factors can thus influence the synthesis of these bio-active molecules having specific protective role in plants [5] [6]. Consequently, their content in plants is highly variable and controlled by a broad spectrum of factors of both intrinsic (e.g. the genotype) [7] and extrinsic nature such as the environmental conditions of the growing area (temperature, light exposure) [8]-[10] and the cropping systems utilized (conventional, organic, biodynamic) [11]-[13]. Therefore, the understanding of the variations in the phytochemicals content in relation to the aforementioned factors will significantly contribute to optimizing both the genetic potential of new cultivars and the growing system applied. Differences between organic and biodynamic agriculture, compared to the conventional one, rely on the cultivation systems. The organic and biodynamic agriculture don't utillize synthetic inputs (fertilizers and pesticides) and green manures, compost and crop rotation are applied; furthermore specific preparations (fermented substances) are utilized by the biodynamic system such as field sprays and compost inoculants. The biodynamic cultivation system has shown to have beneficial impacts on the soil fertility. This is mainly due to a higher organic matter content and biological activity [14] [15]. The low nitrogen supply which characterizes these two cultivation systems has been associated with higher levels of phenolic compounds synthesis in plants [12] [16] [17]. In a previous study carried out on strawberry [13], the biodynamic system was found to significantly increase the synthesis of some bioactive molecules (ascorbic acid, pelargonidin-3-glucoside, cyanidin-3-glucoside, quercetin and kaempferol and ellagic acid) compared to the conventional one.

This study was undertaken to evaluate the influence of the cultivation system on some nutritional traits of the tomato CXD271BIO breeding line (Solanum lycopersicum L.), a cultivar of potential interest for organic cultivation. To achieve this purpose, starting from 2009, the same tomato cultivar (CXD271BIO) was cultivated following conventional, organic and biodynamic growing systems. The impact of the different growing systems on phenolic acids (chlorogenic, caffeic, p-coumaric, ferulic), macronutrients, minerals $(\mathrm{Ca}, \mathrm{K}, \mathrm{Mg}, \mathrm{P}, \mathrm{Na})$ and trace elements $(\mathrm{Fe}, \mathrm{Zn}, \mathrm{Cu}, \mathrm{Mn})$ content in the selected tomato $\mathrm{cv}$. was assessed.

\section{Materials and Methods}

\subsection{Plant Material and Cultivation Systems}

Tomatoes, belonging to the breeding line CXD271BIO (Solanum lycopersicum L.), 
were grown in the same area in center Italy (Lazio region) following conventional, organic and biodynamic growing systems. The analyses were carried out over a cultivation period from 2010 to 2014 . The biodynamic cultivation was performed in a model growing system following a changeover (starting from 2009) of part of an organic farm to biodynamic cultivation. Tomatoes were cultivated outdoors in two field replicates on the ground, without any kind of ground covering. The cover crop was tilled in the soil (green manure) and was composed of Italian clover (Trifolium incarnatum), Egyptian clover (Trifolium alexandrinium), white lupin (Lupinus albus), oats (Avena sativa) and sunflower (Helianthus annuus). Tomatoes cultivation was preceded by crop rotation, with a sequential planting of brassica, courgette and fennel. The biodynamic cultivation was performed following two types of manuring to improve the fertility and biodiversity of the microfauna and microflora of the soil: A) Biodynamic with treatments (compost, 500p, 501 and green manure); B) Biodynamic without treatments, only compost and green manure (multifloreal) was used. The 500p and 501 are the original biodynamic preparations; the 500 preparation (horn-manure) is made from cow manure (fermented in a cow horn that is buried in the soil for six months through autumn and winter) and it is used as a soil spray to stimulate root growth and humus formation. The 501 preparation (horn-silica) is made from powdered quartz (packed inside a cow horn and buried in the soil for six months to spring and summer) and applied as a foliar spray to stimulate and regulate growth. The compost composition is the following: 502 yarrow blossoms (Achillea millefollium), 503 chamomile blossoms (Camomilla officinalis), 504 stinging nettle (Urtica dioica), 505 oak bark (Quercus robur), 506 dandelion flowers (Taraxacum officinale), 507 valerian flowers (Valeriana officinalis). All the plants were irrigated following the same irrigation frequency, time and flow. Tomatoes of all the cultivation types, over three growing seasons (2010, 2012 and 2014), were harvested at ripe stage, randomly picked from different rows of the respective cultivation system and $5 \mathrm{Kg}$ of each were delivered directly to the laboratory. Undamaged tomatoes were pooled into 3 batches, on the basis of the cultivation system utilized. On each batch three independent analyses were performed. Some aliquots were directly analyzed, others were stored at $-30^{\circ} \mathrm{C}$ until analysis.

\subsection{Methods}

\subsubsection{Proximate Analysis}

Moisture, protein (nitrogen $\mathrm{x}$ 6.25), lipid and ash were determined by AOAC methods [18]. Carbohydrates content was calculated by difference.

\subsubsection{Minerals and Trace Elements}

Samples were analyzed for minerals (Ca, Mg, K, P, Na) and trace elements ( $\mathrm{Fe}, \mathrm{Zn}, \mathrm{Cu}$, $\mathrm{Mn}$ ) contents by ICP-Plasma (Optima 3200XL-Perkin-Elmer) after liquid ashing (4 mL $\mathrm{HNO}_{3}+1 \mathrm{~mL} \mathrm{H}_{2} \mathrm{O}_{2}$ ) in a microwave digestion system (Milestone, $1200 \mathrm{Mega}$ ). Standard Reference Materials: Cabbage (IAEA-359, International Atomic Energy Agency Reference Materials Group) and Haricots vert (BCR 383, Community Bureau of Reference, Brussels) were analyzed as a proof for the accuracy of the analyses. 


\subsubsection{Phenolic Acids}

Caffeic, p-coumaric and ferulic acids were separated by RP-HPLC (Waters 996) equipped with a detector PAD, on an Alltima C18 column (4.6 mm - $250 \mathrm{~mm}$, Alltech Associates) following the method by [19]. For caffeic, $p$-coumaric and ferulic acids a liquid/liquid extraction by diethylether $(0.01 \%$ BHT) was carried out after room temperature acid hydrolysis under a nitrogen flow. Chlorogenic acid was extracted by a methanol/12.5\% acetic acid mixture (85/15) in an ultrasonic bath without the hydrolysis step following the extraction method by [20]. The extracted solutions were dried in a rotavapor system at $3^{\circ} \mathrm{C}$ and the residues dissolved in the mobile phase (A: $\mathrm{HCOOH}$ $0.5 \%$; $\left.\mathrm{B}: \mathrm{CH}_{3} \mathrm{CN}, \mathrm{HCOOH} 0.5 \%\right)$. Gradient elution was performed for caffeic, p-coumaric, ferulic and chlorogenic acids (A 95\%; $45 \mathrm{~min}$, A 5\%; $50 \mathrm{~min}$, A 5\%). The quantification of phenolic compounds was performed using the calibration curves of their respective standards. The calibration curves were linear in the range studied with a correlation coefficient of 0.999 .

\subsubsection{Statistical Analysis}

The effect of cultivation system and harvesting year on the phenolic acids and minerals content was evaluated by means of a t-test analysis. The effect was considered significant at $\mathrm{P}<0.05$. Principal component analysis was performed on the phenolic acids and minerals data.

\section{Results and Discussion}

\subsection{Proximate Composition}

Mean data on proximate composition in tomatoes grown by conventional, organic and two types of biodynamic growing systems (A, B) are shown in Table 1. Moisture content was significantly higher $(\mathrm{p}<0.05)$ in the conventionally grown tomatoes compared to the organically and the biodynamically grown ones, by contrast it was very similar among the three types of organic growing systems (Table 1).

These results agree with previous studies showing a trend toward a low moisture content in organic food compared to conventional ones [21]-[23]. Significant differences $(\mathrm{p}<0.05)$ in ash content, only between conventional and organic tomatoes, were observed (Table 1). With regard to protein content, Biodynamic A (with treatments) tomatoes showed the highest protein content $(1.34 \mathrm{mg} / 100 \mathrm{~g})$, the differences in protein content were significant $(\mathrm{p}<0.05)$ among all the growing systems except that between conventional vs. biodynamic B (without treatment) (Table 1). No differences were evidenced in lipid content; carbohydrates content resulted significantly lower $(\mathrm{p}<0.05)$ in the conventionally grown tomatoes compared to the other growing systems, but no differences were observed among tomatoes grown by organic and biodynamic $\mathrm{A}$ and $\mathrm{B}$ growing systems (Table 1).

\subsection{Minerals and Trace Elements}

Mean data on minerals and trace elements content are shown in Table 1. Among minerals, both $\mathrm{Ca}$ and $\mathrm{Na}$ content was significantly higher $(\mathrm{p}<0.05)$ in conventional 
Table 1. Proximate composition, minerals and trace elements content in tomato (cv. CXD 271BIO).

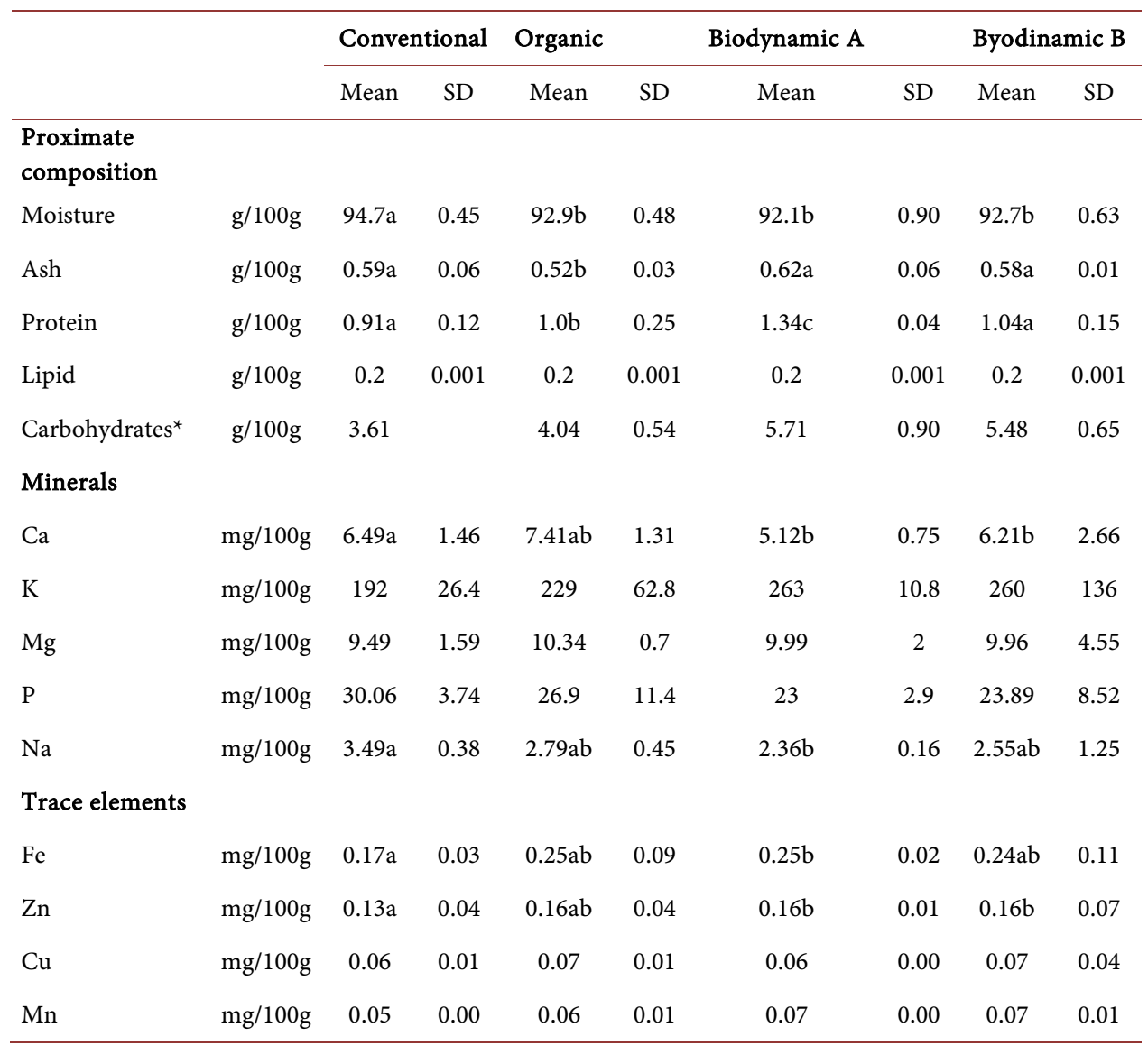

Values are the Mean and SD of three determinations. ${ }^{*}$ Carbohyrates: calculated by differences. Values in the same row followed by different letters indicate significant differences $(\mathrm{p}<0.05)$.

tomatoes compared to the biodynamic $\mathrm{A}$ and $\mathrm{B}$ ones, probably due to the different fertilization approach utilized (Table 1). As far as trace elements were concerned, significant differences $(\mathrm{p}<0.05)$ were observed in Fe content between conventional vs. biodynamic A tomatoes as well in $\mathrm{Zn}$ content between conventional vs. both biodynamic $\mathrm{A}$ and biodynamic $\mathrm{B}$ tomatoes. By contrast, no differences in minerals and trace elements content among the organic and biodynamic ( $\mathrm{A}$ and $\mathrm{B}$ ) growing systems were observed. It is conceivable that, as the mineral composition of the soil is strictly dependent on the cultivation system, the fertilization treatments applied by both organic and biodynamic cultivations resulted in a similar soil composition of the three experimental fields.

\subsection{Phenolic Acids}

Figure 1 shows the phenolic acids content in tomatoes by both year of harvest and cultivation system. Chlorogenic acid was the most abundant among the phenolic acids (Figure 1(a)). Higher amounts of chlorogenic acid were detected in tomatoes of all the growing systems in the last harvesting year (2014) compared to the other two years 


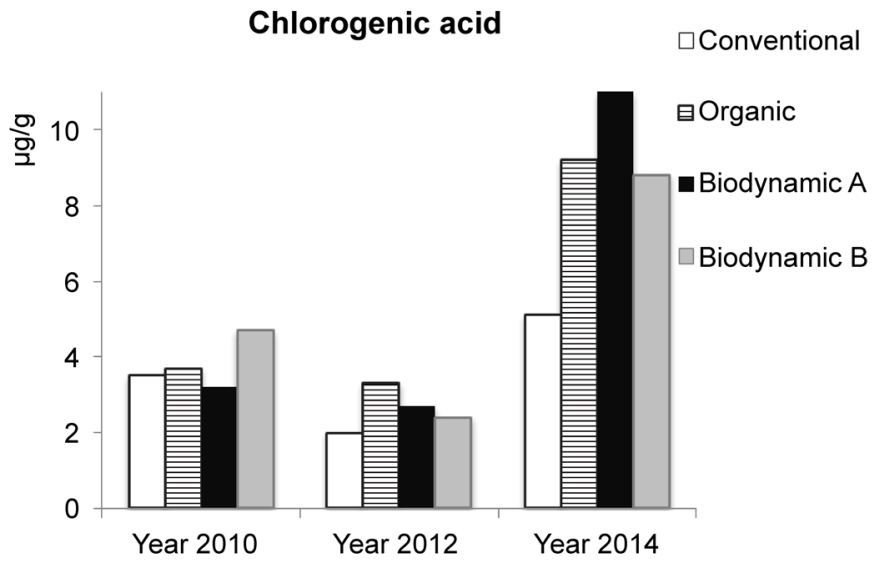

(a)

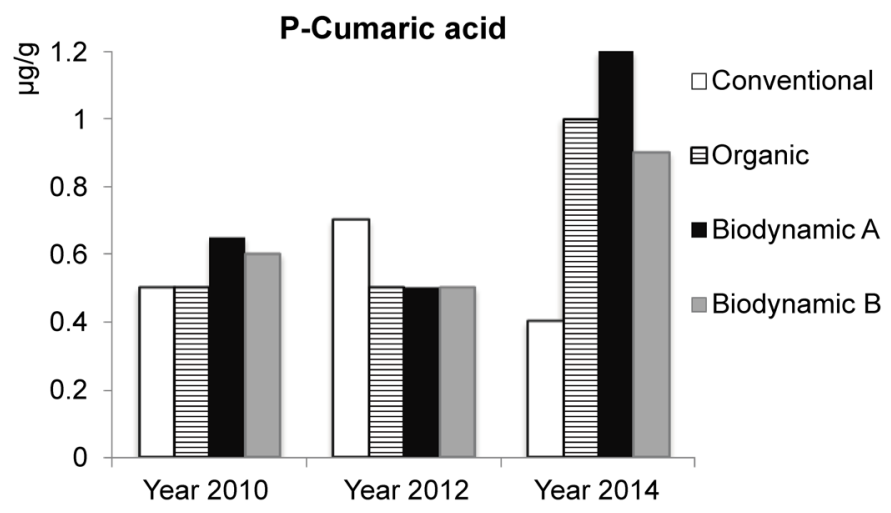

(c)

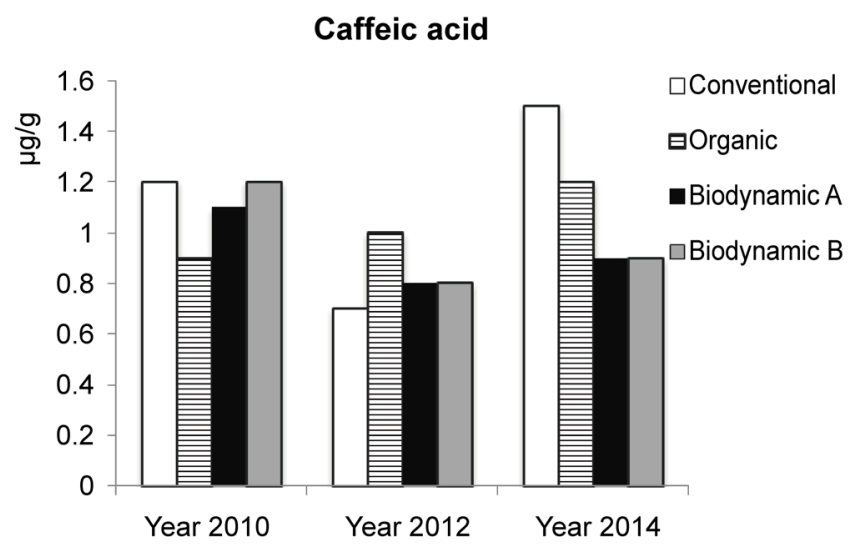

(b)

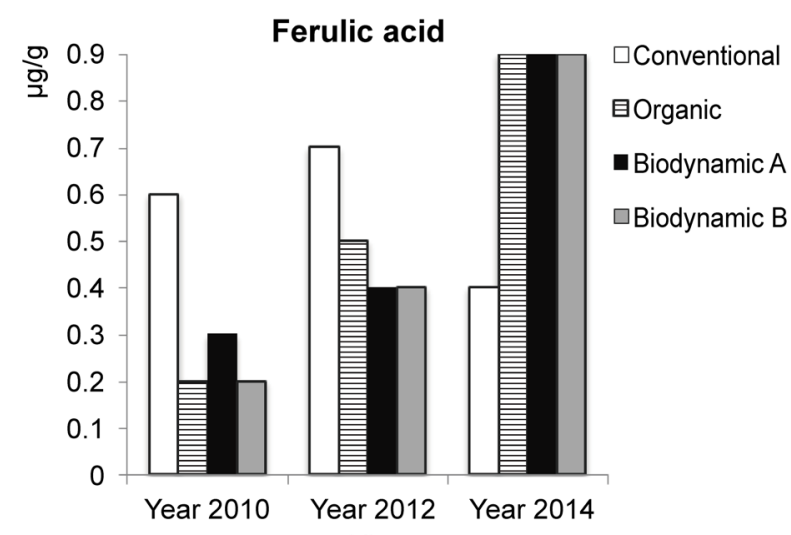

(d)

Figure 1. Chlorogenic (a), caffeic (b), p-cumaric (c) and ferulic (d) acids content ( $\mu \mathrm{g} / \mathrm{g}$ ) in tomato (cv. CXD271BIO) from different growing systems by harvesting year.

(Figure 1(a)); the differences among the growing systems were found significant ( $\mathrm{p}<$ 0.05) only the last cultivation year (2014), when conventionally grown tomatoes showed lower amounts compared to the other growing systems. Caffeic acid showed a very low range of variation both among cultivation systems and harvesting years (Figure 1(b)). In the framework of defense mechanisms, special attention is deserved to $p$-coumaric and ferulic acids because of their ability to form esterified bonds with the cell wall's polysaccharides. An increase in their content is thought to be related to an augmented fruit firmness and, consequently, to an increase in tissue mechanical resistance to pathogen attack [24]. In this study both $p$-coumaric and ferulic acids showed differences in their content only among the harvesting years. $P$-coumaric acid doubled its content form the first (2010) to the last (2014) harvesting year (Figure 1(c)); ferulic acid content in the last harvesting year (2014) was 4.5 times higher compared with both 2010 and 2012 harvesting years (Figure 1(d)). Furthermore, in the last harvesting year (2014), significantly lower amounts $(\mathrm{p}<0.05)$ of ferulic acid were found in the conventionally grown tomatoes compared to the other cultivation systems (Figure $1(\mathrm{~d})$ ). The phenolic acids content in the tomato cultivar analyzed in this study was lower com- 
pared to the literature [25]-[28]. Previous studies reported cultivar to be the major factor contributing to the phenolic acids content in tomato [29] [30], this becomes an emerging factor especially when fruits are grown under similar environmental conditions [31]. Previous studies [31] [32] also pointed out that growing season had a large impact on the variability of phenolic compounds content compared to the cultivation system. In order to evaluate the overall effect of both the cultivation system and harvesting year, a principal components analysis (PCA) was performed on the phenolic acids and minerals matrix as an exploratory and non-supervised data analysis. The principal components (PC) 1 and 2 explain $62.9 \%$ of the total variance, and the plot (Figure 2) shows a separated distribution of the samples according to the harvesting year along PC 1, with the exception of conventional fruits harvested on 2010. The high effect of the harvesting year could be related to the climatic condition, since the biosynthesis of these molecules is very sensitive to solar radiation [33]. On the other hand, the plot shows a separated distribution of samples from conventional growing system regarding all types of organic cultivation (Organic, Biodynamic A, Biodynamic B) along PC 2, with the exception of fruits from organic growing system harvested on 2012 (Figure 2). Therefore, the results of the PCA suggest the harvesting year as the main source of variance on phenolic acids and minerals content in tomato, with the second source of variance represented by the growing system (conventional or organic type systems).

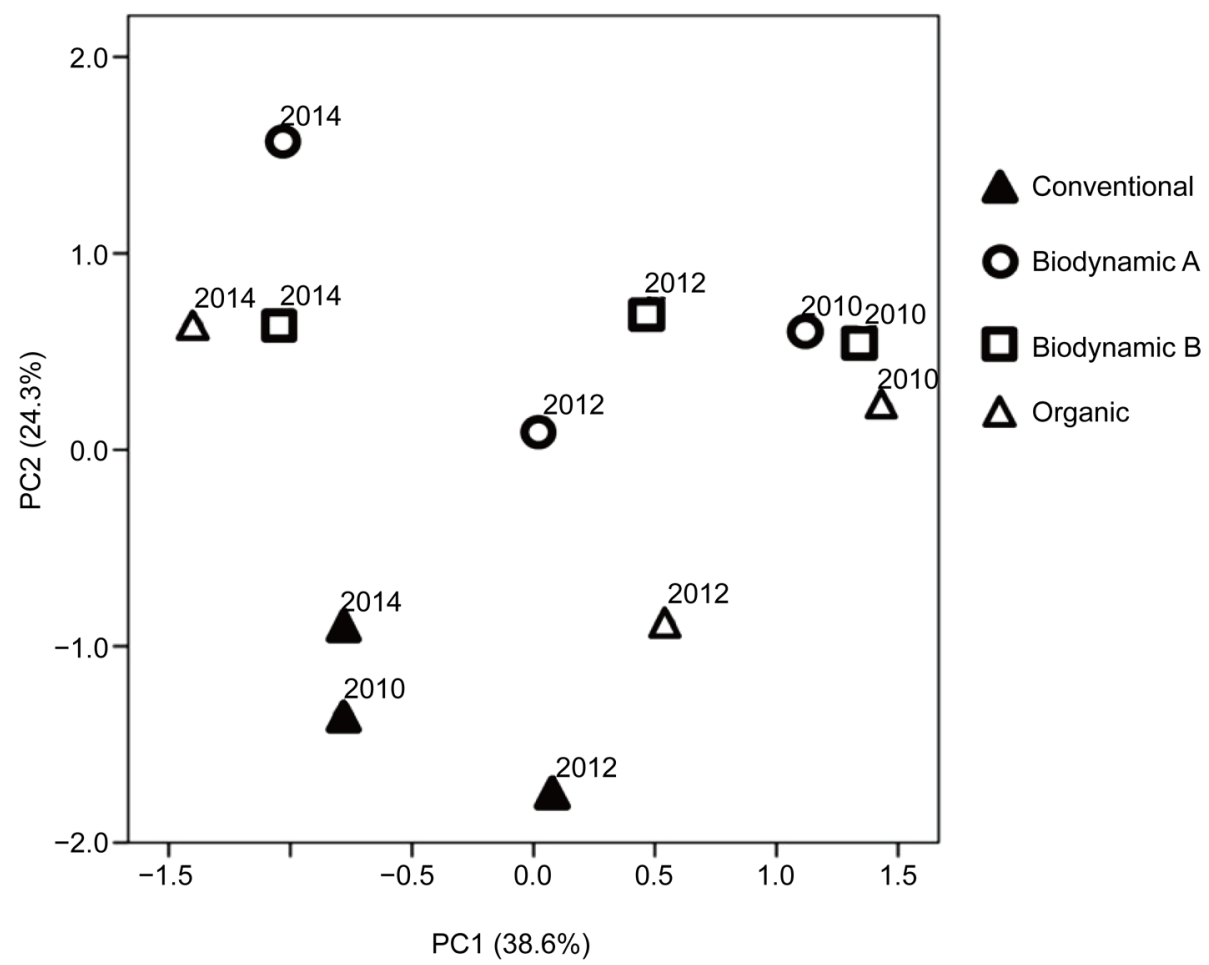

Figure 2. Score plot obtained by the PCA analysis (PC1 vs. PC2) of minerals, trace elements and phenolic acids data matrix from tomato fruits grown by different growing systems in 3 harvesting years $(2010,2012,2014)$ and percentage of total variance explained by each PC. 


\section{Conclusion}

In this study, tomatoes of the same cultivar were grown following conventional and three types of organic cultivation (Organic, Biodynamic A and Biodynamic B) in the same area. This allowed preventing the variability due to the location of the farm, length of insolation, climate and genetic factors. Our findings indicate that the growing system had only marginal effect on nutritional properties of the tomato cultivar studied. Similarly, data on minerals and trace elements content did not provide evidence of major impact of the fertilization among organic and the two biodynamic growing systems, whereas differences (mainly in $\mathrm{Ca}, \mathrm{Na}, \mathrm{Fe}$ and $\mathrm{Zn}$ content) were observed between conventional and biodynamic tomatoes. Appreciable differences in phenolic acids content among the harvesting years rather than among the growing systems were observed. The exploratory and non-supervised analysis of the PCA performed on phenolic acids and minerals content confirmed the harvesting year as the main factor affecting tomato composition, with a lower effect of the growing system which separated the conventional cultivation system regarding the three types of organic cultivation (Organic, Biodynamic A and Biodynamic B). Therefore, since phenolic acids are important bioactive molecules for human health, further long-term studies may provide more insight about the adaptation of the cultivar to the cultivation practices with respect to this specific nutritional trait.

\section{Acknowledgements}

This research was supported by ARSIAL (Regional Agency of the development and the innovation of the agriculture of Lazio Region).

\section{References}

[1] Leclercq, C., Arcella, D., Piccinelli, R., Sette, S., Le Donne, C. and Turrini, A. (2009) The Italian National Food Consumption Survey INRAN-SCAI 2005-2006: Main Results in Terms of Food Consumption. Public Health Nutrition, 12, 2504-2532. http://dx.doi.org/10.1017/S1368980009005035

[2] Arts, I.C.W. and Hollman, P.C.H. (2005) Polyphenols and Disease Risk in Epidemiologic Studies. American Journal of Clinical Nutrition, 81, 317S-325S.

[3] Scalbert, A., Manach, C., Morand, C., Remesy, C. and Jimenez, L. (2005) Dietary Polyphenols and the Prevention of Diseases. Critical Reviews in Food Science and Nutrition, 45, 287-306. http://dx.doi.org/10.1080/1040869059096

[4] Zhang, Y., Seeram, N.P., Lee, R., Feng, L. and Heber, D. (2008) Isolation and Identification of Strawberry Phenolics with Antioxidant and Human Cancer Cell Antiproliferative Properties. Journa of Agriculture and Food Chemistry, 56, 670-675. http://dx.doi.org/10.1021/jf071989c

[5] Dixon, R.A. and Paiva, N.L. (1995) Stress-Induced Phenylpropanoid Metabolism. Plant Cell, 7, 1085-1097. http://dx.doi.org/10.1105/tpc.7.7.1085

[6] Manach, C., Scalbert, A., Morand, C., Rémésy, C. and Jimenez, L. (2004) Polyphenols: Food Sources and Bioavailability. American Journal of Clinical Nutrition, 79, 727-747.

[7] Fiehn, O. (2002) Metabolomics-The Link between Genotypes and Phenotypes. Plant Molecular Biology, 48, 155-171. http://dx.doi.org/10.1023/A:1013713905833 
[8] Wang, S.Y., Chen, C.T. and Wang, C.Y. (2009) The Influence of Light and Maturity on Fruit Quality and Flavonoid Content of Red Raspberries. Food Chemistry, 112, 676-684. http://dx.doi.org/10.1016/j.foodchem.2008.06.032

[9] Slimestad, R. and Verheul, M. (2009) Review of Flavonoids and Other Phenolics from Fruits of Different Tomato (Lycopersicon esculentum Mill.) Cultivars. Journal of the Science of Food and Agriculture, 89, 1255-1270. http://dx.doi.org/10.1002/jsfa.3605

[10] Giuntini, D., Graziani, G., Lercari, B., Fogliano, V., Soldatini, G.F. and Ranieri, A. (2005) Changes in Carotenoid and Ascorbic Acid Contents in Fruits of Different Tomato Genotypes Related to the Depletion of UV-B Radiation. Journal of Agriculture and Food Chemistry, 53, 3174-3181. http://dx.doi.org/10.1021/jf0401726

[11] Asami, D.K., Hong, Y., Barret, D.M. and Mitchell, A.E. (2003) Comparison of the Total Phenolic and Ascorbic Acid Content of Freeze-Dried and Air-Dried Marionberry, Strawberry, and Corn Grown Using Conventional, Organic and Sustainable Agricultural Practices. Journal of Agriculture and Food Chemistry, 51, 1237-1241. http://dx.doi.org/10.1021/jf020635c

[12] Lombardi-Boccia, G., Lucarini, M., Lanzi, S., Aguzzi, A. and Cappelloni, M. (2004) Nutrients and Antioxidant Molecules in Yellow Plums (Prunus domestica L.) from Conventional and Organic Productions: A Comparative Study. Journal of Agriculture and Food Chemistry, 52, 90-94. http://dx.doi.org/10.1021/jf0344690

[13] D’Evoli, L., Tarozzi, A., Hrelia, P., Lucarini, M., Cocchiola, M., Gabrielli, P., Franco, F., Morroni, F., Cantelli-Forti, G. and Lombardi-Boccia, G. (2010) Influence of Cultivation System on Bioactive Molecules Synthesis in Strawberries: Spin-Off on Antioxidant and Antiproliferative Activity. Journal of Food Science, 75, 94-99. http://dx.doi.org/10.1111/j.1750-3841.2009.01435.x

[14] Stolze, M., Piorr, A., Häring, A. and Dabbert, S. (2000) The Environmental Impacts of Organic Farming in Europe. Organic Farming in Europe: Economics and Policy, Volume 6. Department of Farm Economics, University of Hohenheim, Stuttgart.

[15] Tuomisto, H.L., Hodge, I.D., Riordan, P. and Macdonald, D.W. (2012) Does Organic Farming Reduce Environmental Impacts? A Meta-Analysis of European Research. Journal Environmental Manage, 112, 207-216.

[16] Brandt, K. and Mølgaard, J.P. (2001) Organic Agriculture: Does It Enhance or Reduce the Nutritional Value of Plant Foods? Journal of Science of Food and Agriculture, 81, 924-931. http://dx.doi.org/10.1002/jsfa.903

[17] Lea, U., Slimestad, R., Smedvig, P. and Lillo, C. (2007) Nitrogen Deficiency Enhances Expression of Specific MYB and bHLH Transcription Factors and Accumulation of End Products in the Flavonoid Pathway. Planta, 225, 1245-1253. http://dx.doi.org/10.1007/s00425-006-0414-x

[18] AOAC (2012) Official Methods of Analysis, 19th Edition, Association of Official Analytical Chemists, Arlington.

[19] Hanna, P., Naim, M., Rousseff, R.L. and Zehavi, U. (1991) Distribution of Bound and Free Phenolic Acids in Oranges (Citrus sinensis) and Grapefruits (Citrus paradisi). Journal of Science of Food and Agriculture, 57, 417-426. http://dx.doi.org/10.1002/jsfa.2740570312

[20] Awad, M.A., De Jage, A. and Van Westing, L.M. (2000) Flavonoid and Chlorogenic Acid Levels in Apple Fruit: Characterisation of Variation. Science of Horticulture-Amsterdam, 83, 249-263. http://dx.doi.org/10.1016/S0304-4238(99)00124-7

[21] D’Evoli, L., Moscatello, S., Baldicchi, A., Lucarini, M., Cruz-Castillo, J.G., Aguzzi, A., Gabrielli, P., Proietti, S., Battistelli, A., Famiani, F., Bohm, V. and Lombardi-Boccia, G. (2013) 
Post-Harvest Quality, Phytochemicals and Antioxidant Activity in Organic and Conventional Kiwifruit (Actinidia deliciosa, cv. Hayward). Italian Journal of Food Science, 25, 362368.

[22] Worthington, V. (2001) Nutritional Quality of Organic versus Conventional Fruits, Vegetables and Grains. Journal of Alternative Complementary Medicine, 7, 161-173. http://dx.doi.org/10.1089/107555301750164244

[23] Bourne, D. and Prescott, J. (2002) A Comparison of the Nutritional Value, Sensory Qualities, and Food Safety of Organically and Conventionally Produced Foods. Critical Review Food Science and Nutrition, 42, 1-34. http://dx.doi.org/10.1080/10408690290825439

[24] Smith, B.G. and Harris, P.J. (2001) Ferulic Acid Is Esterified to Glucuronoarabinoxylans in Pineapple Cell Walls. Phytochemistry, 56, 513-519. http://dx.doi.org/10.1016/S0031-9422(00)00401-5

[25] Liu, C.H., Cai, L.Y., Lu, X.Y., Han, X.X. and Ying, T.J. (2012) Effect of Postharvest UV-C Irradiation on Phenolic Compound Content and Antioxidant Activity of Tomato Fruit during Storage. Journal of Integrative Agriculture, 11, 159-165. http://dx.doi.org/10.1016/S1671-2927(12)60794-9

[26] Durazzo, A., Azzini, E., Foddai, M.S., Nobili, F., Garaguso, I., Raguzzini, A., Finotti, E., Tisselli, V., Del Vecchio, S., Piazza C., Perenzin, M., Plizzari, L. and Maiani, G. (2010) Influence of Different Crop Management Practices on the Nutritional Properties and Benefits of tomato -Lycopersicon esculentum cv Perfectpeel. International Journal of Food Science and Technology, 45, 2637-2644. http://dx.doi.org/10.1111/j.1365-2621.2010.02439.x

[27] Raffo, A., La Malfa, G., Fogliano, V., Maiani, G. and Quaglia, G. (2006) Seasonal Variations in Antioxidant Compounds of Cherry Tomatoes (Lycopersicon esculentum cv Naomi F1). Journal of Food Composition and Analysis, 19, 11-19. http://dx.doi.org/10.1016/j.jfca.2005.02.003

[28] Hallmann, E. (2012) The Influence of Organic and Conventional Cultivation Systems on the Nutritional Value and Content of Bioactive Compounds in Selected Tomato Types. Journal of the Science of Food and Agriculture, 92, 2840-2848. http://dx.doi.org/10.1002/jsfa.5617

[29] Binoy, G., Charanjit, K., Khurdiya, D.S. and Kapoor, H.C. (2004) Antioxidants in Tomato (Lycopersium esculentum) as a Function of Genotype. Food Chemistry, 84, 45-51. http://dx.doi.org/10.1016/S0308-8146(03)00165-1

[30] Vallverdú-Queralt, A., Medina-Ramón, A., Martínez-Huélamo, M., Júregui, O., AndrésLacueva, C. and Lamuela-Raventos, R.M. (2011) Phenolic Profile and Hydrophilic Antioxidant Capacity as Chemotaxonomic Markers of Tomato Varieties. Journal of Agriculture and Food Chemistry, 59, 3994-4001. http://dx.doi.org/10.1021/jf104400g

[31] Stewart, A.J., Bozonnet, S., Mullen, W., Jenkins, G.I., Lean, M.E.J. and Crozier, A. (2000) Occurrence of Flavonols in Tomatoes and Tomato-Based Products. Journal of Agriculture and Food Chemistry, 48, 2663-2669. http://dx.doi.org/10.1021/jf000070p

[32] Anton, D., Matt, D., Pedastsaar, P., Bender, I., Kazimierczak, R., Roasto, M., Kaart, T., Luik, A. and Püssa, T. (2014) Three-Year Comparative Study of Polyphenol Contents and Antioxidant Capacities in Fruits of Tomato (Lycopersicon esculentum Mill.) Cultivars Grown under Organic and Conventional Conditions. Journal of Agriculture and Food Chemistry, 62, 5173-5180. http://dx.doi.org/10.1021/jf500792k

[33] Luthriaa, D.L., Mukhopadhyaya, S. and Krizekb, D.T. (2006) Content of Total Phenolics and Phenolic Acids in Tomato (Lycopersicon esculentum Mill.) Fruits as Influenced by Cultivar and Solar UV Radiation. Journal of Food Composition and Analysis, 19, 771-777. http://dx.doi.org/10.1016/j.jfca.2006.04.005 
Submit or recommend next manuscript to SCIRP and we will provide best service for you:

Accepting pre-submission inquiries through Email, Facebook, LinkedIn, Twitter, etc. A wide selection of journals (inclusive of 9 subjects, more than 200 journals)

Providing 24-hour high-quality service

User-friendly online submission system

Fair and swift peer-review system

Efficient typesetting and proofreading procedure

Display of the result of downloads and visits, as well as the number of cited articles

Maximum dissemination of your research work

Submit your manuscript at: http://papersubmission.scirp.org/

Or contact fns@scirp.org 